\title{
Pengaruh Whistleblowing System, Budaya Organisasi dan Moralitas Individu Terhadap Pencegahan Fraud pada PT. Pelabuhan Indonesia III (Persero) Benoa Bali
}

\author{
Komang Candra Restalini Anandya*, Desak Nyoman Sri Werastuti \\ Universitas Pendidikan Ganesha, Singaraja, Bali, Indonesia \\ *komang.candra.restalini@undiksha.ac.id
}

\author{
Riwayat Artikel: \\ Tanggal diajukan: \\ 26 Juni 2020 \\ Tanggal diterima: \\ 29 Agustus 2020 \\ Tanggal dipublikasi: \\ 31 Agustus 2020
}

Kata kunci: Pencegahan Fraud, Whistleblowing System, Budaya Organisasi, Moralitas Individu

\section{Pengutipan:}

Anandya, K. C. R., \& Werastuti, D. N. S. (2020). Pengaruh Whistleblowing System, Budaya Organisasi dan Moralitas Individu Terhadap Pencegahan Fraud pada PT. Pelabuhan Indonesia III (Persero) Benoa Bali Jurnal IImiah Akuntansi dan Humanika, 10(2), 185-194

\begin{abstract}
Abstrak
Penelitian ini dilakukan untuk meneliti pengaruh whistleblowing system, budaya organisasi dan moralitas individu terhadap pencegahan fraud pada PT. Pelabuhan Indonesia III (Persero). Penelitian ini menggunakan analisis berupa angka dari variabel tersebut, oleh karena itu peneliti menggunakan pendekatan kuantitatif. Populasi pada penelitian ini ialah seluruh pegawai (karyawan) yang bekerja pada PT. Pelabuhan Indonesia III (Persero) yaitu sebanyak 65 pegawai. Sampel penelitian ini ditentukan dengan teknik sampling jenuh (sensus) yang memiliki arti bahwa seluruh populasi penelitian dijadikan sampel. Data dikumpulkan menggunakan kuesioner dengan skla yang digunakan yaitu skala likert. Kemudian data dianalisis dengan beberapa analisis yakni uji kualitas data yang meliputi uji validitas dan uji reliabilitas, uji statistik deskriptif, uji asumsi klasik yang meliputi uji normalitas, uji multikolinieritas, uji heteroskedastisitas dan uji autokorelasi, serta analisis regresi linier berganda yang dibantu oleh program SPSS 25 . Hasil penelitian menunjukkan bahwa whistleblowing system memiliki pengaruh positif dan signifikan terhadap pencegahan fraud, budaya organisasi memiliki pengaruh positif dan signifikan terhadap pencegahan fraud, dan moralitas individu memiliki pengaruh positif dan signifikan terhadap pencegahan fraud.
\end{abstract}




\section{Pendahuluan}

Pelanggaran terhadap suatu ketentuan sering terjadi pada suatu perusahaan, baik oleh karyawan maupun perusahaan itu sendiri. Kasus pelanggaran ini mencakup pelanggaran hukum berdasarkan perundang-undangan maupun peraturan yang telah diberlakukan di perusahaan. Pelanggaran itu berupa kecurangan (fraud) dan hampir terjadi pada semua jenjang karyawan, mulai jenjang paling bawah, menengah, bahkan sampai jajaran atas (top management) di dalam suatu perusahaan. Menurut (Tjahjono, 2013) kecurangan dapat diartikan tindakan sengaja di luar aturan yang bertujuan menguntungkan diri sendiri dan merugikan orang lain.

Kecurangan yang terjadi di suatu perusahaan tidak mudah untuk dideteksi, karena itu perusahaan memerlukan banyak pihak untuk dapat mengungkapkan suatu tindakan kecurangan (fraud). Pengungkapan fraud dapat dilakukan oleh pihak dalam walaupun pihak luar perusahaan. Pengendalian internal yang baik sangat diperlukan dalam mendeteksi kecurangan dan sekalipun dapat mencegah terjadinya hal tersebut. Pengendalian ini merupakan sebuah proses yang dirancang oleh pihak-pihak internal perusahaan untuk tercapainya beberapa tujuan (Bodnar, 2006) Tujuan tersebut antara lain, pelaporan keuangan yang dilakukan secara reliabel, operasi-operasi perusahaan dilaksanakan secara efisien dan efektif, dan implementasi seluruh kegiatan perusahaan disesuaikan dengan peraturan yang sudah ditetapkan

Pengendalian internal perusahaan didesain supaya dapat mencapai tujuan perusahaan dengan baik, dengan cara selalu mengawasi dan memberikan pengarahan kepada pihak-pihak yang berada di perusahaan, agar nantinya bisa berjalan dengan efektif dan efisien, dan mampu mendeteksi serta mencegah adanya kecurangan. Menurut (Semendawai, Abdul Haris, 2011) dijelaskan bahwa pengendalian internal di suatu perusahaan, untuk mencapainya tidak terlepas dari penerapan suatu whistleblowing system. Perusahaan yang mengimplementasikan sistem ini ialah perusahaan yang sudah melaksanakan sebuah prinsip go public salah satunya yakni GCG (Good Corporate Governance). Banyak perusahaan di Indonesia telah menerapkan sistem ini, PT. Pelabuhan Indonesia III (Persero) merupakan salah satu perusahaan tersebut.

Terdapat fenomena kecurangan yang terjadi di PT. Pelindo III (Ramdhani, 2018) Ditemukan sejumlah tindak pelanggaran norma ketenagakerjaan pada perusahaan Pelindo III yang berada di daerah Maumere yang merupakan satu wilayah regional dengan Benoa, dimana tindak pelanggaran tersebut berupa pembayaran upah di bawah upah minimum. Banyak tenaga kerja bongkar muat yang bekerja keras sehari penuh tanpa adanya upah lembur. Salah satu pekerja menuturkan bahwa alasan ia mendapat upah di bawah minimum karena terdapat potongan PPh 23, namun nyatanya nama karyawan tersebut tidak terdapat dalam daftar pembayaran PPh 23. Dapat dilihat bahwa pihak yang dirugikan tidak dapat mengimplementasikan whistleblowing system padahal kejadian tersebut bisa saja dilaporkan pada media sistem pelaporan pelanggaran yang dimiliki oleh Pelindo III, misalnya saja melalui email dengan melampirkan bukti-bukti yang sebenarnya terjadi.

Kecurangan (fraud) terjadi karena adanya suatu opportunity (peluang atau kesempatan) yang dapat disebabkan oleh beberapa permasalahan, seperti: pengendalian internal yang berjalan tidak baik yang berujung menjadi lemah, kurangnya pengawasan, serta adanya kewenangan yang disalahgunakan sehingga dapat dengan mudah melakukan kecurangan. Elemen opportunity merupakan bagian dari fraud diamond theory yang diusulkan oleh (Wolfe \& Hermanson, 2004).Teori tersebut terdiri dari empat elemen, meliputi opportunity yang sering disebut dengan peluang, pressure yang kerap disebut dengan tekanan, rasionalisasi dan yang terakhir adalah kemampuan.

(Tuanakotta, 2010) menyatakan bahwa terdapatnya sebuah mekanisme dalam pendeteksian dini jika terjadi suatu masalah dari adanya pelanggaran adalah salah satu manfaat dari whistleblowing system. (Miceli, M., Near, J., dan Dworkin, 2008) menyatakan bahwa whistleblowing ialah sebuah pemberitahuan atau penyampaian informasi dari salah satu anggota organisasi maupun perusahaan atau pihak lain dari organisasi, dimana penyampaian ini berhubungan mengenai perilaku menyimpang atau diluar dari peraturan 
yang berlaku oleh seseorang yang melakukannya di dalam ruang lingkup perusahaan. Seseorang yang menyampaikan ini sering disebut dengan istilah whistleblower.

Adanya sistem ini bukan hanya bertujuan sebagai sarana untuk menyalurkan tindakan kecurangan, namun sistem ini juga tidak langsung menjadi sebuah sarana untuk mengawasi kegiatan antar anggota. Keberadaan sistem ini, memberikan efek takut kepada setiap karyawan untuk melakukan kecurangan karena pada saat melakukan kegiatan satu sama lain telah melakukan pengawasan. Hal inilah yang menyebabkan dapat mencegah suatu tindakan fraud yang akan terjadi. Adapun penelitian oleh (Nugroho, 2015) serta (Agusyani et al., 2016) menghasilkan suatu kesimpulan penelitian yang sama, yakni variabel whistleblowing system memiliki pengaruh secara signifikan dan positif terhadap pencegahan kecurangan. Berlandaskan hal tersebut, maka hipotesis penelitian yang bisa dirumuskan yaitu:

\section{$\mathrm{H}_{1}$ : Whistleblowing System Berpengaruh Positif Terhadap Pencegahan Fraud.}

Rasionalisasi atas tindakan fraud (kecurangan) yang terjadi di dalam lingkungan pekerjaan dapat memungkinkan tindakan menyimpang dianggap sebagai tindakan yang benar dan dapat diterima oleh semua orang. Dari adanya rasionalisasi atas tindakan kecurangan, maka diperlukannya suatu budaya organisasi yang baik. Model atau pola organisasi yang dapat diterima oleh tindakan sera memecahkan suatu permasalahan, mengatur maupun membentuk pegawai yang bisa beradaptasi dengan lingkungan dan mempersatukan anggota dari suatu organisasi ialah pengertian dari budaya organisasi (Riani, 2010). Elemen rasionalisasi merupakan bagian dari fraud diamond theory yang diusulkan oleh (Wolfe \& Hermanson, 2004). Teori tersebut terdiri dari empat elemen, meliputi opportunity yang sering disebut dengan peluang, pressure yang kerap disebut dengan tekanan, rasionalisasi dan yang terakhir adalah kemampuan.

Menurut (Arens, A.A., Elder, R.J., dan Beasley, 2008) budaya melakukan segala hal dengan jujur dan etika yang tinggi menjadi salah satu fakor dalam mencegah terjadinya kecurangan. Secara tidak langsung akan menyebabkan individu sebagai karyawan yang menerapkan budaya tersebut dapat memiliki suatu sifat dan sikap untuk merasakan ikut memiliki atau sering disebut dengan sense of belonging serta memiliki rasa bangga karena menjadi bagian dari sebuah organisasi atau yang sering disebut dengan sense of identity. Menurut teori Arens dalam (Tunggal, 2011), meningkatkan budaya organisasi degan melaksanakan seluruh prinsip GCG dapat mencegah terjadinya kecurangan.

Dalam penerapannya, PT. Pelabuhan Indonesia III memiliki 3 (tiga) budaya organisasi yang utama, yakni : 1) customer focus, 2) care serta 3) integrity. Dari ketiga budaya organisasi tersebut, difokuskan pada budaya organisasi integrity yang mewajibkan seluruh pihak perusahaan untuk bertindak disiplin, jujur, adil, terbuka (transparan) serta menjalankan tugas dengan penuh tanggung jawab, maka jika buadaya organisasi ini diimplementasikan dengan baik secara maksimal akan mampu meminimalisir maupun mencegah terjadinya tindak kecurangan. (Zelmiyanti \& Lili Anita, 2015) serta (Sumendap, Priscillia, 2019) menghasilkan suatu kesimpulan penelitian yang sama, yakni variabel budaya organisasi berpengaruh secara signifikan dan positif terhadap pencegahan kecurangan. Berlandaskan hal tersebut, maka hipotesis penelitian yang bisa dirumuskan yaitu:

\section{$\mathbf{H}_{2}$ : Budaya Organisasi Berpengaruh Positif Terhadap Pencegahan Fraud.}

Kecurangan dapat dicegah dengan baik jika sikap dan budaya dari masing-masing individu tergolong baik, sikap tersebut sering disebut dengan moralitas (Purwitasari, 2013). Menurut teori dari (Kohlberg, 1995) tentang level penalaran moral menyatakan bahwa tingkatan dari masing-masing penalaran individu dapat menjadi cerminan bagaimana individu tersebut akan melakukan tindakan. Level penalaran moral ini juga dapat dikaitkan dalam hal dilema etika.

Pencegahan kecurangan sangat erat kaitannya dengan moralitas. Tidak menutup kemungkinan bahwa orang-orang yang cukup berpengaruh di suatu perusahaan dapat melakukan tindakan yang tidak benar dikarenakan memiliki suatu capability/capacity 
(kemampuan), ini merupakan sifat berasal dari dalam individu yang melakukan suatu penipuan yang memanfaatkan kesempatan untuk melakukan kecurangan. Elemen kemampuan merupakan bagian dari teori dasar yang diuji dalam penelitian, yakni fraud diamond. Konsep teori baru ini diusulkan oleh (Wolfe \& Hermanson, 2004)

Kasus kecurangan lain pada PT. Pelabuhan Indonesia III bertempat di Surabaya (Jajeli, 2016). Dijelaskan bahwa adanya kasus pungli (pungutan liar), yang mengecewakan adalah yang melakukan hal ters.ebut adalah seseorang yang memiliki jabatan tinggi pada perusahaan tersebut yaitu Direktur Utama, istrinya, dan juga Direktur Operasional dan Pengembangan. Kasus ini merupakan kasus pungutan liar berupa uang sebesar Rp. 500 ribu hingga Rp. 2 juta dimana dilakukan kepada kontainer impor yang ada pada Terminal Petikemas Surabaya.

Dilihat dari hasil sejumlah studi yang dijelaskan dalam (Liyanarachchi \& Newdick, 2009) menyatakan bahwa perilaku etis dari individu cenderung dipengaruhi oleh tingkatan penalaran moral. Tingkat penalaran moral yang tinggi ini bisa mempengaruhi seseorang untuk bertindak dengan benar dan begitupun sebaliknya. Adapun penelitian oleh (Laksmi \& Sujana, 2019) serta (Rahimah et al., 2018) menghasilkan suatu kesimpulan penelitian yang sama, yakni variabel moralitas individu memiliki pengaruh secara positif terhadap pencegahan kecurangan. Berlandaskan hal tersebut, maka hipotesis penelitian yang bisa dirumuskan yaitu:

\section{$\mathrm{H}_{3}$ : Moralitas Individu Berpengaruh Positif Terhadap Pencegahan Fraud.}

\section{Metode}

Penelitian ini menggunakan analisis berupa angka dari variabel yang digunakan, oleh karena itu menggunakan pendekatan kuantitatif. Populasi dijelaskan sebagai sebuah area yang biasanya terdiri dari karakteristik dan kualitas dari suatu objek atau subjek dimana nantinya ditentukan sebagai bahan untuk dipelajari (Sugiyono, 2013). Seluruh pegawai (karyawan) yang bekerja di PT. Pelabuhan Indonesia III (Persero) Benoa, Bali merupakan populasi dari penelitian ini yang dimana berjumlah 65 orang pegawai.

Sebagian jumlah dari populasi dari suatu penelitian disebut dengan sampel penelitian (Sugiyono, 2013). Jumlah populasi kurang dari 100 yakni hanya sebanyak 65 orang, maka teknik pengambilan sampel ialah sensus (sampling jenuh). Menurut (Sugiyono, 2013)teknik ini merupakan pengambilan sampel yang menggunakan keseluruhan populasi.

Data dikumpulkan dengan menggunakan teknik kuesioner. Kuesioner tersebut akan diberikan berupa pernyataan tertulis mengenai seluruh variabel yaitu whistleblowing system, budaya organisasi, moralitas individu dan juga pencegahan fraud. Setelah data terkumpul maka dianalisis dengan menggunakan beberapa analisis yaitu uji kualitas data, analisis statistik deskriptif, uji asumsi klasik dan analisis regresi linier berganda.

\section{Hasil dan Pembahasan}

Valid atau tidak suatu data dapat diuji dengan uji validitas, apabila nilai sig (signifikansi) < 0,05 (5\%) maka dinyatakan valid, sedangkan jika nilai sig (signifikansi) $>0,05$ (5\%) maka dinyatakan tidak valid. Uji validitas di penelitian ini menggunakan Pearson Correlation melalui program SPSS versi 25 dengan data responden yang berjumlah 65 karyawan. Sebelumnya dilakukan pilot test untuk uji validitas dan uji reliabilitas. Uji validitas masing-masing pernyataan kuesioner memiliki nilai signifikasi 0,00 yaitu dibawah 0,05 . Maka bisa disimpulkan bahwa semua item pernyataan pada kuesioner adalah valid. Uji yang digunakan untuk mengetahui kuesioner reliabel atau tidak adalah uji reliabilitas. Jawaban dari setiap pernyataan yang konsisten merupakan cerminan dari kuesioner yang handal dan reliabel. Suatu instrumen atau variabel dikatakan reliabel bila mempunyai Cronbach's Alpha $>0,70$. Berdasarkan hasil pengujian masing-masing variabel diperoleh data bahwa nilai Cronbach's Alpha > 0,70. Jadi, dapat disimpulkan seluruh variabel di penelitian ini dapat dikatakan reliabel atau konsisten.

Statistik deskriptif merupakan salah satu proses dalam mentransformasi data dengan menabulasinya, yang nantinya dapat dengan mudah dimengerti dan dapat dijelaskan dengan baik. Proses ini menggunakan ukuran berupa nilai terendah, nilai tertinggi, rata-rata 
dan juga standar deviasi dari masing-masing data variabel. Statistik deskriptif di penelitian ini melalui program SPSS versi 25 dengan jumlah responden sebanyak 65 karyawan. Hasil dari statistik deskriptif yang telah diolah melalui program tersebut disajikan di tabel berikut.

Tabel 1. Hasil Analisis Statistik Deskriptif

\begin{tabular}{lccccc}
\hline $\begin{array}{c}\text { Variabel } \\
\text { Penelitian }\end{array}$ & N & Min & Max & Mean & $\begin{array}{c}\text { Std. } \\
\text { Deviation }\end{array}$ \\
\hline Whistleblowing & 65 & 12 & 20 & 17,23 & 2,037 \\
System & & 18 & 30 & 25,23 & 3,306 \\
Budaya Organisasi & 65 & 16 & 25 & 21,17 & 2,504 \\
Moralitas Individu & 65 & 35 & 28,72 & 4,079 \\
Pencegahan Fraud & 65 & 21 & & & \\
\hline
\end{tabular}

Pengujian data yang mencerminkan normal atau tidak adalah uji normalitas. Hasil pengujian menggunakan uji analisis metode Kolmogorov Smirnov. Nilai Asymp.Sig (2-tailed) variabel residual berada di atas 0,05 atau $5 \%$ artinya data berdistribusi secara normal. Pengujian ini mendapatkan hasil bahwa nilai Asymp.Sig (2-tailed) sebesar 0,300, maka menunjukkan bahwa sebaran data berdistribusi secara normal.

Uji multikolinieritas memiliki fungsi dalam menjelaskan ada atau tidaknya multikolinieritas di suatu model regresi. Indikasi adanya multikolinearitas yaitu apabila Tolerance lebih dari 0,10 serta VIF kurang dari 10 maka tidak terjadi multikolinearitas. Pengujian ini mendapatkan hasil bahwa nilai VIF masing-masing variabel bebas tidak lebih dari 10 dan nilai Tolerance masing-masing variabel lebih dari 0,10. Maka bisa disimpulkan bahwa antara variabel bebas tidak terjadi multikolinieritas.

Uji heteroskedastisitas digunakan untuk mengetahui data mengalami ketidaksamaan variasi residual. Adanya gejala heterskedastisitas dapat diuji dengan uji Glejser, tidak terjadi gejala tersebut apabila nilai sig (signifikansi) lebih besar dari 0,05 . Pengujian ini mendapatkan hasil dimana nilai siginifikansi dari masing-masing variabel lebih besar dari 0,05 . Oleh karena itu, bisa disimpulkan bahwa tidak terjadi masalah heteroskedastisitas.

Tujuan dari uji autokrelasi yaitu untuk menguji atau mengetahui apakah di dalam suatu data penelitian terdapat atau tidak korelasi antar kesalahan pengganggu pada periode tertentu dengan periode sebelumnya. Ada tidaknya autokorelasi dapat dihitung dengan nilai Durbin-Watson (dw). Nilai dw dianggap tidak bermasalah jika berada pada kondisi du<dw<4du. Pengujian ini mendapatkan hasil bahwa tidak terdapat masalah atau gejala autokorelasi, sedangkan untuk pengaruh whistleblowing system, budaya organisasi dan moralitas individu terhadap pencegahan fraud dapat dilihat di tabel 2.

Tabel 2. Hasil Analisis Regresi Berganda

\begin{tabular}{lrrl}
\hline \multicolumn{1}{c}{ Model } & $\begin{array}{c}\text { Unstandardized } \\
\text { Coefficients B }\end{array}$ & \multicolumn{1}{l}{$t$} & Sig. \\
\hline Constant & $-3,540$ & $-1,658$ & 0,103 \\
Whistleblowing System & 0,626 & 3,445 & 0,001 \\
Budaya Organisasi & 0,629 & 5,451 & 0,000 \\
Moralitas Individu & 0,265 & 2,014 & 0,048 \\
\hline
\end{tabular}

Berlandaskan Tabel 2 di atas, maka didapatkan persamaan regresi linear berganda seperti berikut:

$$
\begin{aligned}
& \mathrm{PF}=\alpha+\beta 1 \mathrm{WBS}+\beta 2 \mathrm{BO}+\beta 3 \mathrm{Ml}+\varepsilon \\
& \mathrm{PF}=(-3,540)+0,626 \mathrm{WBS}+0,629 \mathrm{BO}+0,265 \mathrm{Ml}+\varepsilon \\
& \text { Keterangan: } \\
& \mathrm{PF} \quad=\text { Pencegahan Fraud } \\
& \alpha \quad=\text { konstanta persamaan regresi }
\end{aligned}
$$




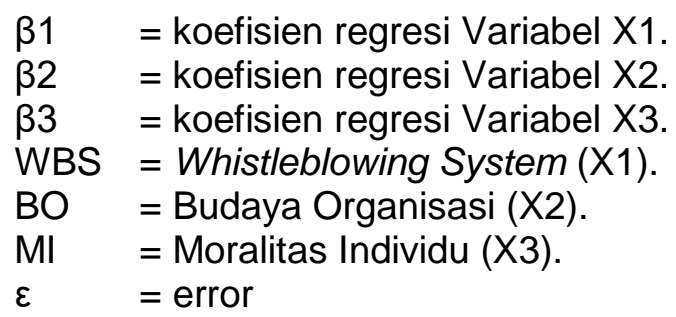

Dari persamaan regresi linear berganda yang terbentuk, dapat diinterpretasikan sebagai berikut : pertama, Nilai konstanta ( $\alpha$ ) yakni $-3,540$, artinya jika tidak terjadi perubahan variabel whistleblowing system, budaya organisasi, moralitas individu (nilai $\mathrm{X}_{1}, \mathrm{X}_{2}$ dan $\mathrm{X}_{3}$ ialah 0) maka variabel pencegahan fraud $(\mathrm{Y})$ memiliki nilai sebesar -3,540 satuan. Kedua, Nilai koefisien regresi whistleblowing system $\left(X_{1}\right)$ adalah 0,626, artinya jika variabel whistleblowing system meningkat sebesar 1 satuan dengan asumsi bahwa variabel yang lain adalah tetap (konstan), maka variabel pencegahan fraud $(Y)$ meningkat sebesar 0,626 . Nilai koefisien regresi yang positif ini juga menunjukkan bahwa whistleblowing system berpengaruh (berkontribusi) positif terhadap pencegahan fraud. Ketiga, Nilai koefisien regresi budaya organisasi $\left(X_{2}\right)$ adalah 0,629 , artinya jika variabel budaya organisasi meningkat sebesar 1 satuan dengan asumsi bahwa variabel yang lain adalah tetap (konstan), maka variabel pencegahan fraud $(Y)$ meningkat sebesar 0,629. Nilai koefisien regresi yang positif ini juga menunjukkan bahwa budaya organisasi berpengaruh (berkontribusi) positif terhadap pencegahan fraud. Keempat, Nilai koefisien regresi moralitas individu $\left(\mathrm{X}_{3}\right)$ adalah 0,265 , artinya jika variabel moralitas individu meningkat sebesar 1 satuan dengan asumsi bahwa variabel yang lain adalah tetap (konstan), maka variabel pencegahan fraud $(Y)$ meningkat sebesar 0,265 . Nilai koefisien regresi yang positif ini juga menunjukkan bahwa moralitas individu berpengaruh (berkontribusi) positif terhadap pencegahan fraud.

\section{Pengaruh Whistleblowing System Terhadap Pencegahan Fraud}

(Tuanakotta, 2010) menyatakan bahwa terdapatnya sebuah mekanisme dalam pendeteksian dini jika terjadi suatu masalah dari adanya pelanggaran adalah salah satu manfaat dari sistem pelaporan pelanggaran. Whistleblowing system ialah sistem yang berguna untuk melaporkan adanya tindak kecurangan. Suatu tindakan seseorang atau sejumlah karyawan dalam melakukan pelaporan atas tindakan pelanggaran yang terjadi di perusahaan atau yang dilakukan oleh pihak pimpinan kepada pihak luar perusahaan (pihak lain) adalah pengertian dari whistleblowing (Brandon, 2013). Whistleblower sendiri ialah sebutan bagi seorang individu atau kelompok yang bersedia melakukan sebuah pelaporan atas tindakan fraud. Kecurangan bisa disebabkan oleh adanya suatu kesempatan atau peluang (opportunity).

Penelitian ini mendapatkan hasil nilai signifikansi dari variabel whistleblowing system yaitu 0,001<0,05 serta memiliki suatu koefisien regresi 0,626 ini memiliki arti bahwa variabel whistleblowing system berpengaruh secara signifikan dan positif terhadap pencegahan kecurangan (fraud), jadi dapat diartikan hipotesis pertama $\left(\mathrm{H}_{1}\right)$ diterima. Hal ini juga memiliki arti bahwa semakin tinggi atau baik penerapan dari sistem pelaporan pelanggaran (whistleblowing system) di perusahaan maka semakin tinggi atau baik juga upaya dalam mencegah terjadinya suatu tindak kecurangan (fraud).

Adanya sistem pelaporan pelanggaran (whistleblowing system) ini secara tidak langsung merupakan sebuah bentuk pengawasan di suatu perusahaan. Pegawai (karyawan) menjadi segan dalam melakukan kecurangan dikarenakan sistem pelaporan pelanggaran ini dapat dipakai oleh semua pegawai, maka dampaknya antar pegawai satu dengan yang lainnya menjadi saling mengawasi. Hal ini sejalan dengan manfaat dari adanya whistleblowing system menurut (Tuanakotta, 2010) yang menyatakan bahwa timbulnya keengganan dalam melakukan suatu tindak pelanggaran, dikarenakan semakin meningkatnya kesediaan seseorang untuk melakukan pelaporan atas terjadinya tindak pelanggaran (kecurangan). Hal ini terjadi karena adanya sutau kepercayaan pada sistem 
pelaporan pelanggaran yang efektif. Inilah yang nantinya secara tidak langsung dapat menyebabkan pencegahan suatu tindakan kecurangan (fraud).

Penelitian yang dilakukan oleh (Nugroho, 2015) serta (Agusyani et al., 2016) mendukung hal tersebut, dimana menghasilkan suatu kesimpulan penelitian yang sama, yakni variabel sistem pelaporan pelanggaran (whistleblowing system) memiliki pengaruh secara signifikan dan positif terhadap pencegahan kecurangan. Adapun penelitian yang dilakukan oleh (Suastawan et al., 2017) juga mendukung hal tersebut, dimana secara parsial dan simultan whistleblowing system memiliki pengaruh secara signifikan dan positif terhadap pencegahan kecurangan (fraud).

\section{Pengaruh Budaya Organisasi Terhadap Pencegahan Fraud}

Salah satu bentuk atau penyebab kecurangan ialah adanya suatu rasionalisasi atas tindakan kecurangan. Rasionalisasi ini menjadikan penipu melihat tindakan ilegalnya sebagai suatu hal yang dapat diterima oleh orang lain. Adanya rasionalisasi atas tindakan kecurangan ini, maka diperlukannya suatu budaya organisasi yang baik. Model atau pola dasar yang dapat diterima oleh organisasi dalam melakukan tindakan serta memecahkan suatu permasalahan, mengatur maupun membentuk pegawai yang bisa beradaptasi dengan lingkungan dan mempersatukan anggota dari suatu organisasi ialah pengertian dari budaya organisasi (Riani, 2010). Budaya organisasi juga digunakan sebagai pedoman untuk mengontrol perilaku anggota.

Penelitian ini mendapatkan hasil yakni nilai signifikansi dari variabel budaya organisasi yaitu 0,000 $<0,05$ serta memiliki suatu koefisien regresi 0,629 ini berarti variabel budaya organisasi memiliki pengaruh secara signifikan dan positif terhadap pencegahan kecurangan (fraud), jadi dapat diartikan hipotesis kedua $\left(\mathrm{H}_{2}\right)$ diterima. Ini pula memiliki arti bahwa semakin tinggi atau baik penerapan dari budaya organisasi di perusahaan maka semakin tinggi atau baik juga upaya dalam mencegah terjadinya suatu tindak kecurangan (fraud).

Hasil penelitian ini sejalan bersama teori Arens yang menjelaskan tentang salah satu aspek yang dapat mencegah suatu tindak kecurangan ialah budaya yang jujur serta etika yang tinggi, dimana ini secara tidak langsung dapat memiliki sifat dan sikap untuk rasa ikut mempunyai serta rasa bangga menjadi bagian dari organisasi setelah karyawan menerapkan budaya organisasi itu sendiri. Teori ini juga diperkuat oleh (Tunggal, 2011) dimana menjelaskan bahwa tindakan fraud bisa dicegah melalui cara meningkatkan suatu budaya organisasi dengan mengimplementasikan prinsip-prinsip GCG (Good Corporate Governance).

Dalam pelaksanaannya, PT. Pelabuhan Indonesia III memiliki 3 (tiga) budaya organisasi yang utama, yakni : 1) customer focus, 2) care serta 3) integrity. Dari ketiga budaya organisasi tersebut, difokuskan pada budaya organisasi integrity yang mewajibkan seluruh pihak perusahaan untuk bertindak disiplin, jujur, adil, terbuka serta menjalankan semua kewajiban dengan tanggung jawab yang penuh. Pencegahan fraud dapat berjalan dengan baik sesuai dengan tujuannya, apabila salah satu budaya organisasi yang dimiliki dapat diterapkan dengan sebaik mungkin.

Penelitian yang dilakukan oleh (Zelmiyanti \& Lili Anita, 2015) serta (Sumendap, Priscillia, 2019) mendukung hal tersebut, dimana menghasilkan suatu kesimpulan penelitian yang sama, yakni variabel budaya organisasi memiliki pengaruh secara signifikan dan positif terhadap pencegahan kecurangan. Adapun penelitian yang dilakukan oleh (Wulandari, 2017) juga mendukung hipotesis, dimana menghasilkan kesimpulan bahwa budaya organisasi mempunyai pengaruh secara positif terhadap pencegahan kecurangan, serta variabel di penelitiannya yang terdiri dari budaya organisasi dan whistleblowing system merupakan variabel yang sangat dominan berpengaruh terhadap pencegahan kecurangan.

\section{Pengaruh Moralitas Individu Terhadap Pencegahan Fraud}

Menurut (Junia, 2016) menyatakan bahwa moralitas (moral) ialah sebuah ajaran mengenai buruk baiknya sifat dan sikap dalam suatu individu seseorang sedangkan pengertian dari bermoral ialah pertimbangan akan buruk baiknya akhlak seseorang. 
Moralitas individu merupakan sebuah ialah perilaku atau sikap yang dimana seseorang melakukan sesuatu mengarah ke hal yang positif atau baik dengan berlandaskan keikhlasan tanpa meminta balasan (tidak pamrih). Seseorang yang memiliki level penalaran moral yang kurang (rendah) mempunyai perilaku berbeda dengan orang yang memiliki level penalaran moral yang baik (tinggi) jika seseorang tersebut menghadapi suatu dilema etika.

Berlandaskan hasil sejumlah studi yang dijelaskan dalam (Liyanarachchi \& Newdick, 2009) menyatakan bahwa perilaku etis dari individu cenderung dipengaruhi oleh tingkatan penalaran moral. Hal ini memiliki arti jika level penalaran moral seseorang semakin tinggi maka semakin mungkin dalam melakukan hal yang baik atau benar. Begitu juga sebaliknya jika level penalaran moral seseorang rendah maka akan semakin mungkin dalam melakukan hal yang tidak baik atau tidak benar. Menurut (Kohlberg, 1995) menjelaskan bahwa terdapat 3 (tiga) tingkatan perkembangan moral yang setiap tingkatan sendiri terdiri dari beberapa tahapan diantaranya: tahap pertama yakni (pre-conventional), tahap kedua yaitu (conventional) dan tahap tertinggi ialah tahap ketiga (post-conventional).

Penelitian ini mendapatkan hasil bahwa nilai signifikansi dari variabel moralitas individu yaitu $0,048<0,05$ serta memiliki suatu koefisien regresi 0,265 hal ini memiliki arti bahwa variabel moralitas individu berpengaruh secara signifikan dan positif terhadap pencegahan kecurangan (fraud), jadi dapat diartikan hipotesis ketiga $\left(\mathrm{H}_{3}\right)$ diterima. Artinya jika moralitas individu seseorang semakin tinggi maka dapat mempengaruhi juga tingginya upaya dalam pencegahan fraud di sebuah perusahaan.

Tingginya level moral yang dimiliki seseorang, akan memungkinkan seseorang tersebut untuk selalu melakukan hal yang benar dan baik dimana sesuai dengan norma serta aturan di sekelilingnya. Melakukan hal yang baik tersebut akan dapat mencegah adanya keinginan untuk melakukan kecurangan. Biasanya seseorang yang taat akan norma, akan mengetahui akibat-akibat atau sanksi yang didapat apabila melanggar aturan dan norma tersebut. Oleh karena itu, moralitas individu dapat mempengaruhi pencegahan fraud.

Moralitas serta kecurangan (fraud) memiliki hubungan yang erat dalam persepsi pencegahan fraud. Suatu tindakan kecurangan berupa pungutan liar terjadi di PT. Pelindo III yang pelaku sendiri merupakan orang yang penting bahkan cukup berpengaruh di dalam perusahaan tersebut. Tidak menutup kemungkinan bahwa orang-orang yang cukup berpengaruh di suatu perusahaan dapat melakukan tindakan yang tidak benar dikarenakan memiliki suatu capability/capacity (kemampuan). Hal ini memiliki arti bahwa jika level penalaran moral seseorang semakin tinggi maka semakin mungkin dalam melakukan hal yang baik atau benar, begitu juga sebaliknya.

Penelitian yang dilakukan oleh (Laksmi \& Sujana, 2019) serta (Rahimah et al., 2018) juga mendukung hal tersebut, dimana menghasilkan suatu kesimpulan penelitian yang sama, yakni variabel moralitas individu memiliki pengaruh yang positif terhadap pencegahan fraud. Adapun penelitian yang dilakukan oleh (Sumendap, Priscillia, 2019) juga mendukung hal tersebut, dimana moralitas individu mempunyai pengaruh positif terhadap pencegahan fraud.

\section{Simpulan dan Saran}

Berdasarkan hasil penelitian yang telah dibahas sebelumnya, maka dapat ditarik suatu kesimpulan, yakni: (1) Whsitleblowing system memiliki pengaruh positif dan signifikan terhadap pencegahan fraud. Hal ini disebabkan karena dalam implementasinya sistem pelaporan pelanggaran ini tidak hanya sebagai saluran pelaporan kecurangan, namun secara tidak langsung merupakan sebuah bentuk pengawasan; (2) Budaya organisasi memiliki pengaruh positif dan signifikan terhadap pencegahan fraud. Difokuskan pada budaya organisasi yang dimiliki oleh perusahaan yakni integrity mewajibkan seluruh pihak perusahaan untuk bertindak disiplin, jujur, adil, terbuka (transparan) serta menjalankan tugas dengan penuh tanggung jawab. maka, budaya organisasi ini jika diimplementasikan dengan baik secara maksimal akan mampu meminimalisir maupun mencegah terjadinya tindak kecurangan; (3) Moralitas individu mempunyai pengaruh secara positif dan signifikan terhadap pencegahan fraud. Hal ini disebabkan oleh suatu level penalaran moral individu seseorang yang dimana mempunyai pengaruh atas perilaku etis orang tersebut. Ini memiliki 
arti bahwa jika level penalaran moral seseorang semakin tinggi maka semakin mungkin dalam melakukan hal yang baik atau benar, begitu juga sebaliknya.

Adapun saran yang dapat disampaikan yaitu bagi perusahaan sebaiknya bisa untuk lebih mengefektifkan serta mengembangkan penerapan whistleblowing system dan budaya organisasi. Bagi karyawan perusahaan, diharapkan mampu meningkatkan lagi penalaran moral individu dan bersedia menjadi seorang whistleblower. Bagi peneliti selanjutnya, diharapkan bisa mengkaji lebih dalam lagi mengenai penelitian ini serta bisa mengembangkan faktor atau variabel lain yang mempengaruhi pencegahan fraud seperti: pemberian kompensasi, efektivitas pengendalian internal, peran auditor internal, kompetensi Sumber Daya Manusia.

\section{Daftar Rujukan}

Agusyani, N. K. S., Sujana, E., \& Wahyuni, M. A. (2016). Pengaruh whistleblowing system dan kompetensi sumber daya manusia terhadap pencegahan fraud pada pengelolaan keuangan penerimaan pendapatan asli daerah. E-Journal Ak Universitas Pendidikan Ganesha.Vol.6, No.3

Arens, A.A., Elder, R.J., dan Beasley, M. . (2008). Auditing dan Jasa Assurance: Pendekatan Terintegrasi. (Alih bahasa: Herman Wibowo). Penerbit Erlangga.

Bodnar, G. H. dan W. S. H. diterjemahkan oleh J. A. S. dan L. S. (2006). Accounting Information System. Yogyakarta: Andi.

Jajeli, R. (2016). Mantan Dirut Pelindo III Terseret Dugaan Pungli, Pengacara: Sudah Tersangka. https://doi.org/https://news.detik.com/berita/d-3342667/mantan-dirutpelindo-iii-terseret-dugaan-pungli-pengacara-sudah-tersangka. Diakses pada tanggal 4 April 2020.

Junia, N. (2016). Pengaruh Moralitas Aparat, Kesesuaian Kompensasi, dan Ketaatan Aturan Akuntansi Terhadap Kecenderungan Kecurangan Akuntansi (Studi Empiris pada Satuan Kerja Perangkat Daerah Kabupaten Kampar). JOM Fekon, Vol.3, No.1, Hal 1623-1637.

Kohlberg, L. (1995). Tahap-tahap Perkembangan Moral. Yogyakarta: Kanisius.

Laksmi, P. S. P., \& Sujana, I. K. (2019). Pengaruh Kompetensi SDM, Moralitas dan Sistem Pengendalian Internal Terhadap Pencegahan Fraud Dalam Pengelolaan Keuangan Desa. E-Jurnal Akuntansi. Vol.26, No.3 https://doi.org/10.24843/eja.2019.v26.i03.p18

Liyanarachchi, G., \& Newdick, C. (2009). The impact of moral reasoning and retaliation on whistle-blowing: New Zealand evidence. Journal of Business Ethics, Vol.8, No.9 https://doi.org/10.1007/s10551-008-9983-x

Miceli, M., Near, J., dan Dworkin, T. (2008). Whistleblowing in organizations. InNew York, NY: Lea's Organization and Management Series, Routledge, Taylor and Francis Group.

Nugroho, V. O. (2015). Pengaruh Persepsi Karyawan Mengenai Whistleblowing System Terhadap Pencegahan Fraud Dengan Perilaku Etis Sebagai Variabel Intervening Pada PT. Pagilaran. Universitas Negeri Yogyakarta.

Purwitasari, A. (2013). Pengaruh Pengendalian Internal dan Komitmen Organisasi dalam Pencegahan Fraud Pengadaan Barang (Survey pada 5 Rumah Sakit di Bandung). Universitas Widyatama Bandung.

Rahimah, L. N., Murni, Y., \& Lysandra, S. (2018). Pengaruh Penyajian Laporan Keuangan 
Desa, Lingkungan Pengendalian dan Moralitas Individu terhadap Pencegahan Fraud yang terjadi dalam Pengelolaan Alokasi Dana Desa. Jurnal IImiah IImu Ekonomi, Vol. 6

Ramdhani, G. (2018). Sidak di Pelindo III Maumere, Menaker Temukan Pelanggaran Ketenagakerjaan. https://doi.org/https://www.liputan6.com/news/read/3664704/sidakdi-pelindo-iii-maumere-menaker-temukan-pelanggaran-ketenagakerjaan.Diakses Tanggal 14 Februari 2020

Riani, A. L. (2010). Budaya Organisasi. Yogyakarta : Graha IImu.

Semendawai, Abdul Haris, et. al. (2011). Memahami Whistle Blower. Lembaga Perlindungan Saksi dan Korban.

Suastawan, I. M. D. P., Sujana, E., \& Sulindawati, N. luh G. (2017). Pengaruh Budaya Organisa, Proactive Fraud Audit, dan Whistleblowing Terhadap Pencegahan Kecurangan dalam Pengelolaan Dana Bos. E-Journal S1 Ak Univ. Pendidikan Ganesha, Vol.1, No.1

Sugiyono. (2013). Metode Penelitian Kuantitatif, Kualitatif dan $R$ dan D. Bandung : Alfabeta.

Sumendap, Priscillia, D. (2019). Pengaruh Budaya Organisasi Dan Moralitas Individu Terhadap Pencegahan Kecurangan Dengan Sistem Pengendalian Internal Sebagai Variabel Intervening. Buku 2 Sosial Dan Humaniora.

Tjahjono, S. dkk. (2013). Business Crime and Ethics: Konsep dan Studi Kasus Fraud di Indonesia dan Global. Yogyakarta : Andi.

Tuanakotta, T. M. (2010). Akuntansi Forensik dan Audit Investigasi (Edisi Kedua). Jakarta : Salemba Empat.

Tunggal, A. W. (2011). Pengantar Kecurangan Korporasi. Jakarta : Harvarindo.

Wolfe, D. T., \& Hermanson, D. R. (2004). The Fraud Diamond: Considering the Four Elements of Fraud. CPA Journal. https://doi.org/DOI:

Wulandari, T. (2017). Pengaruh Budaya Organisasi, Peran Audit Internal, Dan Whistleblowing System Terhadap Pencegahan Kecurangan. Universitas Islam Negeri Syarif Hidayatullah.

Zelmiyanti, R., \& Lili Anita. (2015). Pengaruh Budaya Organisasi dan Peran Auditor Internal Terhadap Pencegahan Kecurangan dengan Pelaksanaan Sistem Pengendalian Internal Sebagai Variabel Intervening. Jurnal Akuntansi Keuangan Dan Bisnis, Vol.8. 